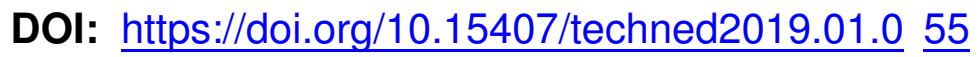

\title{
COMBINED STOCHASTIC TECHNIQUE. COMPARISON OF RESULTS OBTAINED BY DIFFERENT MULTI CRITERIA DECISION MAKING TECHNIQUES
}

Journal

Publisher

ISSN

Issue

Pages
Tekhnichna elektrodynamika

Institute of Electrodynamics National Academy of Science of Ukraine 1607-7970 (print), 2218-1903 (online)

No 1, 2019 (January/February)

$55-62$

\section{Authors}

\section{Lukianenko*, I. Goncharenko**}

Institute of Electrodynamics of National Academy of Sciences of Ukraine,

pr. Peremohy, 56, Kyiv, 03057, Ukraine,

e-mail: okjraa@gmail.com

* ORCID ID : http://orcid.org/0000-0003-1749-5209

** ORCID ID : http://orcid.org/0000-0002-9022-6083

\section{Abstract}

To solve the optimization problem of distributed generation (DG) optimal placement Combined Stochastic Technique [5] has been developed. Components of the objective function is standardized and balanced by weight coefficients. The determination of the latter is proposed to be carried out by an Expert Evaluation Technique (EET). However, such an approach is 
unfounded. Therefore, the object of this paper is to determine whether the obtained with EET weight coefficients correspond with the problem formulation, according to which peculiarities of both power grid and DG must have equal influence on the rating of problem solution. To achieve the object optimal problem solution was determined by multi criteria decision making techniques TOPSIS, VIKOR and VIKOR-kernel. Weight coefficients are defined with Information Entropy Weight Method. Obtained results are practically identical to obtained previously. Therefore, weight coefficients were properly determined by an EET References 9, figure 1, tables 5 .

Key words: distributed generation, Combined Stochastic Technique, multiple criteria decision making, TOPSIS, VIKOR, VIKOR-kernel.

Received: 02.03 .2018

Accepted: 23.07.2018

Published: 10.01 .2019

\section{References}

1. Opricovic S., Tzeng G.-H. Extended VIKOR method in comparison with outranking methods. European Journal of Operational Research. 2007. No 178. Pp. 514-529. DOI: https://doi.org /10.1016/j.ejor.2006.01.020

2. Johnson R.A., Wichern D.W. Applied Multivariate Statistical Analysis. Upper Saddle River, New Jersey: Pearson Prentice Hall, 2007. 773 p.

3. Kudria S.O. State and perspectives of renewable energy development in Ukraine. Visnyk Natsionalnoi Akademii Nauk Ukrainy . 2015. No 12. Pp. 19-26. (Ukr) URL:

http://www.ive.org.ua/wp-content/uploads/Visn_12_2015_6.pdf

(Accessed 10.01.2018) 
4. Kyrylenko O.V., Lukianenko L.M., Goncharenko I.S. The problems of efficient introduction of renewable energy sources into power grids. Proceedings of the $17^{\text {th }}$ International Scientific and Practical Conference Renewable Energy and Energy Efficiency in the 21

st

\section{Century}

. 29-30 September, 2016. Kyiv, Ukraine. Pp. 130-133. (Ukr)

5. Kyrylenko O.V., Lukianenko L.M., Goncharenko I.S. Stochastic approach to determination of the distributed generation optimal placement. Tekhnichna Elektrodynamika. 2017. No 1. Pp. 62-70. (Ukr) DOI:

ttps://doi.org/10.15407/techned2017.01.062

6. Zharkin A.F., Popov V.A., Banuzade Sahragard S., Zamkovoi P.A., Spodynskaia A.V. Multicriteria evaluation of alternative options for the distributed generation sources integration into the distribution networks. Elektronnoe Modelirovanie. 2016. Vol. 38. No 1. Pp. 99-112. (Rus) URL:

http://dspace.nbuv.gov.ua

/bitstream/handle/123456789/101338/08-Zharkin.pdf

(Accessed 10.01.2018)

7. Romanchenko I.S., Potomkin M.M. VIKOR-kernel method and its using to make a multiple criteria alternatives comparison. Modern Information Technologies in the Sphere of Security and Defence //nbuv.gov.ua/UJRN/sitsbo_2015_3_19

(Accessed 10.01.2018)

. 2015. No 3 (24). Pp. 103-107. (Ukr) URL: http:

8. El-Santawy M.F., Ahmed A.N. An Information Entropy Weighting Method Combined to TOPSIS Approach for Ranking Consulting Firms. Life Science Journal. 2012. No 9 (1s). Pp. 147-150. URL:

ww.lifesciencesite.com/lsj/life0901s/023_14628life0901s_147_150.pdf

(Accessed 10.01.2018)

9. Power Systems Test Case Archive of the Department of Electrical Engineering at the University of Washington. URL: http://www.ee.washington.edu/research/pstca/ (Accessed 10.01.2018) 